\title{
Assessing the tourist and recreational potential in the South of Russia
}

\author{
Olga V. Ivlieva, Anna V. Shmytkova*, Roman I. Sukhov, Ksenia V. Kushnir, and Tatyana \\ N. Grigorenko
}

Higher School of Business of Southern Federal University, 105/42 B. Sadovaya Str., 344006 Rostovon-Don, Russia

\begin{abstract}
The article is concerned with the holistic approach to the study of the tourism potential of the South of Russia. The paper presents analyses of various techniques to the research of the tourist opportunities of territories both in Russia and in other countries. Methodological approaches are described in the study of the macroregions tourist potential. The assessment and ranking of the natural, cultural, and socio-economic potential of all administrative entities forming the South of Russia in terms of their importance for tourism have been carried out. The aggregate indicator of tourist and recreational potential of each entity has been calculated. Regions with a high level of tourist and recreational potential, relatively high, average, and relatively low are identified.
\end{abstract}

\section{Introduction}

Tourist potential assessment of destination is an important research area, that allows creating a basis for determining the tourist regional specialization, possibilities of developing priority types of tourism, and, ultimately, target on the audiences of the travel product consumers.

The South of Russia unites thirteen administrative entities of the Russian Federation: The Republic of Adygea, The Karachay-Cherkess Republic, The Kabardino-Balkar Republic, The Republic of North Ossetia - Alania, The Republic of Ingushetia, The Chechen Republic, The Republic of Dagestan, The Republic of Kalmykia, Astrakhan Oblast, Rostov Oblast, Volgograd Oblast, Krasnodar Krai, and Stavropol Krai. The tourist and recreational complex has exceptional importance for the South of Russia because it determines the modern macroeconomic 'face' of the region in many aspects.

An objective assessment of the regional competitiveness, competent planning, and management of tourism and recreation are impossible without the tourist and recreational potential evaluation of the territory, i.e. it is necessary to estimate the natural, historical, cultural and socio-economic potential of its constituent regions. Scientists use various techniques and approaches to research depending on the goals set.

Characterizing the historical and cultural potential, it is worth seeing the scientific works of the authors [1,2]. The most widely used model by professor Hilary Du Cros [3]

\footnotetext{
${ }^{*}$ Corresponding author: annav1109@mail.ru
} 
consists of two aspects: preserving cultural values and commercializing marketability (or managing cultural heritage and tourism development). The author presented a model for planning sustainable tourism and cultural heritage development. It is a three-level matrix in which heritage assets can be divided into nine main areas according to their attractiveness in the tourist market [3].

Mechanisms for assessing the tourism potential of cultural and heritage assets were tested in Hong Kong [1] on a sample of secondary museums, historic sites, and temples. Although their cultural standard and physical security were rated highly, their tourist significance was low. The quantitative approach to measuring the tourism potential of cultural and heritage assets in the form of a mathematical model was proposed by Chinese scientists [4]. The approach was tested on the case of several cultural heritage assets in China. The technique is based on resource values and the state of their development and allows to evaluate various indicators of the tourism potential. Of particular interest are studies aimed at presenting cultural tourism as an active approach to meeting these tourists' needs who want to participate actively in creating experiences during the trip. In this case, the organizers focus on close interaction and cooperation with consumers in the creation of a high-quality product [5].

Some types of tourism depend directly on the natural destination's potential. For example, one can distinguish balneological and rural tourism among promising ones in Serbia. The issues of their development and resource base studies are actively examined in order to outline the potential for further development. The weak points that currently impede the growth of these promising types of tourism are also scrutinized by modern techniques [6, 7]. The Polish scientist Meyer B. [8] considers getting the balance between the environment, tourists, the local community and service providers. The use of natural elements can become the basis for the sustainable development of tourism and complement mass tourism for the development of various forms of niche tourism.

Kusen E. \& Tadej P. [9] worked out an original method for classifying the tourism resource base. They suggest to identify the destination tourist attractiveness and then give recommendations on the ability of its enlisting in the tourist product based on its estimation and significance. Rivero M, Martín J., Gallego J. [10] offer a graduated response model (GRM) that allows establishing the resource's hierarchy by constructing a continuous latent scale where you can arrange every analyzed resource of a tourist destination. The GRM was tested on the rural tourism resources in the Spanish province of Cáceres.

\section{Data and methods}

All entities of the South of Russia are characterized by different tourist and recreational potential indicators and values, presented in numerical terms according to the technique proposed by Tulskaya N. I. and Shabalina N.V. [11]. In order to get the impartial assessment, all quantitative indicators were converted to relative units. For example, 'SPNA (Special Protected Natural Areas)' were converted into 'the SPNA in proportion to the overall regional area'; 'number of beds in accommodation facilities' into 'number of beds in accommodation facilities per 1000 residents', etc.

The assessment procedure of the tourism potential is as follows: 1) the minimum (worst) value of the indicator is found; 2) this value is subtracted from each value; 3 ) the maximum of the resulting values is found; 4) all the values are divided by this maximum value. Then all numerical data are converted into the range from 0 to 1 . Zero - corresponds to the worst integrated assessment, and one - to the best. To obtain the final (single) indicator for each object, we use the simple summation method of the previously standardized values. Interpretation and mapping of the obtained particular and final assessments are carried out in the closing stages of the assessment procedure of tourist and 
recreational potential. An assessment of the tourist and recreational potential, made on the basis of GIS technology, makes it possible to identify priority areas for tourism development and to plan further business strategy in the region based on scientific data.

\section{Results and discussion}

\section{Assessing the natural potential in the South of Russia}

To assess the natural potential of each subject in the South of Russia, the following factors were taken into consideration: the depth of the terrain dissection, prevailing datum level, river density, annual number of sunshine hours, variety of terrains, area under forest, and the SPNA in proportion to the overall regional area, the number of natural landmarks, balneological resources (mineral and mud springs), coastline length, existence of UNESCO world heritage monuments.

The indisputable leader of natural tourist and recreational resources is Krasnodar Krai. It is washed by two seas Black and Azov ones; has hundreds of kilometers of sandy and pebble beaches, and a large number of resorts on these coasts (Yeysk, Anapa, Sochi, Gelendzhik, Tuapse, Adler). Krasnodar Krai occupies one of the leading places in the region on the number of local mineral waters (Matsesta, etc.) and muds. There is the warmest climate in Russia with a large number of sunny days. It has the highest density of the river network, several large rivers flow in the region - the Kuban, Laba, and Belaya, suitable for fishing and rafting. Krai occupies a large territory with a great number of SPNAs. One of the largest nature reserves in Russia Caucasus Nature Reserve has been designated by UNESCO as a World Heritage Site.

The Republic of Adygea is rightfully considered a region of active development of water tourism in Russia. The Belaya River has sections of all 6 ranks of complexity in its course. The republic has the highest rates in the region in terms of river network density, timber condition $(36.6 \%)$, and the number of mineral springs.

Kabardino-Balkaria is located in the central, highest part of the Caucasus, all fivethousandths peaks of the Greater Caucasus, except Kazbek, are in the republic. The highest mountain in Europe Elbrus rises to a height of $5642 \mathrm{~m}$. here. The republic has the highest index of ruggedness relief in the region and one of the highest indicators of the variety of terrains. The part of the SPNA in proportion to the overall regional area is one of the highest in the region. This is Kabardino-Balkarsky Nature Reserve and the Prielbrusye National Park.

The Republic of North Ossetia has the highest average annual number of sunshine hours - 2256. Nearly half of the territory of the republic is occupied by mountains. The significant part of the republic's territory is occupied by SPNAs: The nature sanctuaries Tseysky, North Ossetian, Alaniya National Park.

More than one-third of the territory of The Karachay-Cherkess Republic is occupied by SPNAs. It is the eastern district of the Caucasus Nature Reserve which includes Caucasus Nature Reserve, Teberda Nature Reserve, eight wildlife sanctuaries, 74 natural landmarks.

The steppe, flat territories of the Astrakhan oblast, the Stavropol Krai and Dagestan have an average natural potential. The Astrakhan oblast and the Stavropol Krai have low rates of absolute elevations and shallow depth of ruggedness relief. Small forest area does not exceed $2-3 \%$ of the territory. However, fishermen and hunters will not leave indifferent to the region, because the Volga and Volga-Akhtubinsk bottom-land are rich in fish and wildfowl at any time of the year. The Stavropol Krai is famous for its rich natural balneological resource. There are more 130 mineral water springs in the Caucasian Spas resort area. Dagestan boasts the presence of resorts on the Caspian coast, the length of which is $540 \mathrm{~km}$. 
Kalmykia, Rostov and Volgograd oblasts belong to zones of relatively low natural potential, have the lowest values of all the analyzed parameters.

\section{Cultural and historical potential assessment of the South of Russia}

Cultural and historical potential assessment of the South of Russia was carried out on the basis of seven criteria: the number of museums, theaters, monuments of federal significance, zoos, parks, and stadiums (withstands for 1,500 seats or more) per $1000 \mathrm{~km}^{2}$, as well as the availability of UNESCO World Heritage Sites.

From these estimations, we might distinguish 4 groups of regions. The high level of cultural and historical potential (0.6) is intrinsic to one subject - North Ossetia-Alania. The republic got maximum scores according to three criteria: the number of theaters, stadiums, and zoos per $1000 \mathrm{~km}^{2}$. In a relatively small area of the republic, there are 6 theaters, not only academic but of great interest: The Equestrian Theater "Nartu" and the Ritual Theater "Arvaydan". The rich historical heritage of Ossetia is of great value. Architectural and historical monuments have been preserved on the republic territory.

The second group of regions is characterized by a relatively high cultural and historical potential (0.4-0.6) and includes Dagestan, Ingushetia, and Kabardino-Balkaria. Dagestan is a place of special significance in the South of Russia by the number and magnitude of cultural heritage sites. There are 1960 monuments of history, culture, the architecture of federal importance in the republic. The Citadel, the old city and the fortress of the oldest cultural center of Dagestan - Derbent were included in the UNESCO World Heritage List in 2003. 14 peoples live in Dagestan, the ethnic factor determined a significant number of museums - 99 and theaters - 11, including Azerbaijani, Avarian, Kumyk, Darghin, Lak, Lezghin, Nogai, Tabasaran theaters. Besides, Dagestan is the leader in the number of city parks among the regions of the South of Russia, and in terms of the corresponding indicator per $1,000 \mathrm{~km}^{2}$ it is second only to Ingushetia and North Ossetia.

The third group of regions includes the Krasnodar Krai, Rostov Oblast and the Republic of Adygea and is characterized by an average cultural and historical potential (0.2 - 0.4), spread over the rather large area of the subjects. Rostov Oblast and Krasnodar Krai are leaders in the number of monuments of federal significance in the South of Russia - 8236 and 5177, respectively. These are the monuments of antiquity: Gorgippia, Fanagoria, Hermonassa-Tmutarakan in the Krasnodar Krai and Tanais in the Rostov Oblast, which are part of "The Golden Ring of the Bosporan Kingdom" tour itinerary, and ethnographic objects associated with the Cossacks, and architectural monuments. At the same time, these regions received low scores according to other criteria of the cultural and historical block.

The fourth group consists of 6 subjects with a relatively low level of cultural and historical potential (0-0.2). The cultural potential of these regions is represented mainly by the sights of regional centers: Elista, Volgograd, Astrakhan, Stavropol, Grozny, Cherkessk.

Thus, the distribution of cultural and historical tourist resources in the South of Russia has certain spatial patterns: a number of republics of the Caucasus have significant potential, the Sea of Azov and Black Sea territories have certain cultural resources, and the northeastern part of southern Russia is characterized by a relatively low value of cultural and historical potential, spread over the large area of the subjects.

\section{Assessment of socio-economic potential}

The following criteria were taken into consideration to assess the socio-economic potential: density of roads and railways, the number of beds per head, number of seats in catering facilities per head, the total passenger traffic in the regional airports.

The Krasnodar Krai is an undisputed leader in terms of socio-economic conditions for tourism development in the South of Russia. The region received the highest scores 4 from 5 evaluation criteria. More than $70 \%$ of all the number of beds in collective accommodation facilities in the south are concentrated in the Krasnodar Krai. The region is characterized by a high number of beds in collective accommodation facilities -70 per 1000 population. 391 
thousand places are concentrated in food courts, which corresponds to 70 places per 1000 population in the Krasnodar Krai. The density of railways in the Krasnodar Krai is twice the average for the South. There are 4 airports in the area: Sochi, Krasnodar, Anapa, and Gelendzhik, which account for $54 \%$ of the total passenger traffic airports in the South of Russia.

The Republic of Adygea and North Ossetia-Alania have relatively high socio-economic potential: both republics stand out in terms of places in public catering facilities per head and density of roads and railways, while they have a very small number of places in collective accommodation facilities per head.

The third group of regions is seven entities characterized by the average socio-economic potential for tourism development. All of them, in comparison with the Krasnodar Krai, has rather a small number of places in collective accommodation facilities. At the same time, Rostov Oblast and Stavropol Krai stand out in this group, whose airports account for $27 \%$ of the total passenger flow in the South of Russia. Rostov-on-Don and Mineralnye Vody are the largest railway junctions of the North-Caucasian Railway.

The fourth group of regions, including the republics of Kalmykia, Karachay-Cherkessia, and Dagestan, is characterized by the lowest values of all the analyzed criteria.

The total amount of tourist and recreational potential was calculated as the sum of natural, historical, cultural, and socio-economic potentials divided into the number of blocks (3). The Krasnodar Krai has the highest potential. Relatively high tourist and recreational potential is in the republics of North Ossetia-Alania, Adygea, and KabardinoBalkaria. The average indicator of tourist and recreational potential is typical for the republics: Karachay-Cherkessia, Ingushetia, Chechnya, Dagestan, as well as for the Rostov Oblast and the Stavropol Krai. The Volgograd and Astrakhan Oblasts and Kalmykia have a relatively low value of the total tourist and recreational potential (Fig. 1).

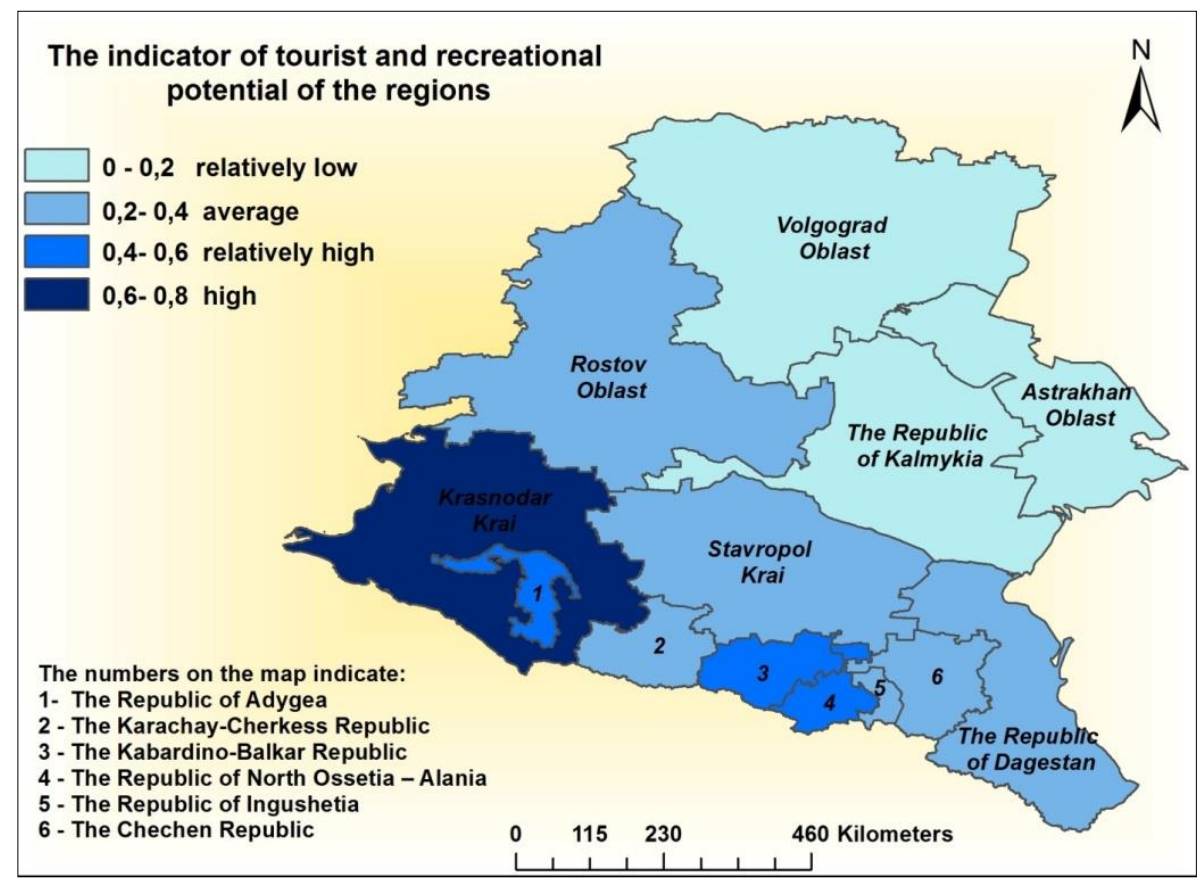

Fig. 1. Typology of regions in terms of tourist and recreational potential 


\section{Conclusions}

The comprehensive assessment of the tourist-recreational potential, i. e. the study and evaluation of all possible resources and conditions of the territory that determine its touristrecreational attractiveness, should become one of the conditions for the formation of a tourist-recreational complex in the South of Russia.

The Krasnodar Krai is the leader in terms of the total tourist and recreational potential in the South of Russia. The holding of the XXII Winter Olympic Games in Sochi in 2014 contributed to the promotion of the tourist destination brand, the rational and uniform use of tourism resources throughout the year, gave impetus to the modernization and development of tourism and transport infrastructure, and facilitated the development of new types of tourism (skiing, ecological, event-based, MICE) along with the traditional for this region sea, sand, sun tourism.

The North Caucasus Republics have significant potential, but the use of resources has been difficult for a long period due to the geopolitical conflicts. After the normalization of the political situation, the tourist flow began to recover. Nowadays tourist clusters are created and actively developing in the republics of the North Caucasus in the framework of public-private partnerships with the support of regional and Federal Targeted Programmes.

Despite the relatively low indicator of tourist and recreational potential in the lowland and foothill territories of the studied macroregion, its resource base allows us to talk about the tourism development at the regional level for the needs of the local population. Furthermore, one should note the development of unique types of tourism peculiar to only for these regions, for example, in Rostov oblast - cultural tours of Cossack and ethnic gastronomical topics, in the Volgograd oblast - military-patriotic subject, in the Republic of Kalmykia - ethnic-religious one, associated with Buddhism, in Astrakhan - nature and hunting and fishing topics, due to the natural resources of the Volga delta.

\section{Acknowledgements}

This research was conducted by the financial support of the Southern Federal University.

\section{References}

1. B. McKercher, P. Sy Ho, Journal of Sustainable Tourism, 14(5), 473 (2006)

2. B. McKercher, H. du Cros, New York: The Haworth Press (2002)

3. H.du Cros, International Journal of Tourism Research, 3(2), 165 (2001)

4. L. Yan, BW. Gao, M. Zhang, Tourism Management, 63, 355 (2017)

5. D. Jovicic, Current Issues in Tourism, 19(6), 605 (2016)

6. M. Todorović, Ž.Bjeljac, Acta geographica Slovenica, 49(2), 453 (2009)

7. A. Valjarević, D. Vukoičić, D. Valjarević, Tourism Management Perspectives, 22, 7 (2017)

8. B. Meyer, Creating tourist space on the basis of natural environment as an element of sustainable development, case of the Stepnica commune. 4th International Scientific Conference ToSEE - Tourism in Southern and Eastern Europe 2017 "Tourism and Creative Industries: Trends and Challenges" Opatija, Croatia, 4 - 6 May 2017, 365 (2017)

9. E. Kusen, P. Tadej, Tourism Review, 51(4), 427 (2003)

10. M. Rivero, J. Martín, J. Gallego, Current Issues in Tourism, 19(11), 1084 (2016) 
11. N. I. Tulskaya, N. V. Shabalina, Mathematical and cartographic modeling to assess the tourist and recreational potential of the territory (on the example of the Central Federal district) (2012), http://www.geogr.msu.ru/ 